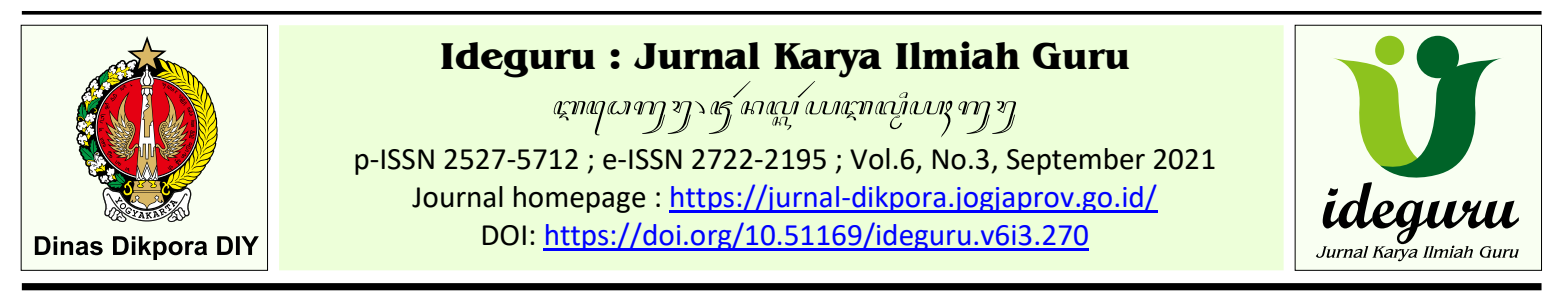

Artikel Penelitian - Naskah dikirim: 03/04/2021 - Selesai revisi: 20/07/2021 - Disetujui: 22/07/2021 - Diterbitkan: 01/09/2021

\title{
Peningkatan Prestasi Belajar Matematika Menggunakan Model Cycle-5e Berbantu Modul Statistika
}

\author{
Riani Widiastuti \\ SMA Negeri 4 Yogyakarta, Yogyakarta, Daerah Istimewa Yogyakarta, Indonesia \\ Rianiw76@gmail.com
}

\begin{abstract}
Abstrak: Arah penelitian ini untuk memaparkan kefektifan penggunaan model Cycle-5e berbantuan modul Statistika dalam menaikkan prestasi belajar siswa kelas XII SMAN 4 Yogyakarta Tahun 2019. Penelitian tindakan dilaksanakan dilaksanakan dalam 4 langkah yaitu: menyusun suatu rencana untuk suatu pengembangan, melaksanakan yang telah direncanakan, mengamati efek tindakan, dan merefleksikan hal-hal yang telah diperoleh. Setiap 4 langkah ini disebut satu putaran (siklus). Hasil yang diperoleh dalam satu siklus belum sesuai dengan yang ditargetkan, diulangi lagi dalam siklus berikutnya, dan seterusnya, sampai siklus tiga. Setelah diterapkan penggunaan Model Cycle-5e berbantu modul Statistika penelitian ini terbukti efektif: 1) Meningkatkan prestasi belajar Matematika siswa kelas XII SMAN 4 Yogyakarta. Hal ini terlihat dari peningkatan ketuntasan belajar siswa setiap siklus dari 13 siswa pada siklus I menjadi 27 siswa pada siklus II, 29 siswa pada siklus III. Ada peningkatan presentase ketuntasan setiap siklus, dari 40,63 pada siklus I naik menjadi $84,38 \%$ pada siklus II, dan $100 \%$ pada siklus III. Prestasi belajar minimal sejumlah 80 siswa mencapai lebih dari Kriteria Ketuntasan Minimal 75. 2)Penggunaan Model Cycle-5E berbantu modul Statistika baik karena adanya tanggapan positif dari siswa. Ini dapat terlihat dari hasil wawancara terhadap sejumlah siswa dan observasi pembelajaran Model Cycle-5e berbantu modul Statistika yang menunjukkan sebagian besar siswa memberikan tanggapan positif dan beberapa siswa memberikan tanggapan negatif.
\end{abstract}

Kata kunci: Cycle-5e; modul statistika; prestasi belajar.

\section{Improvement of Mathematics Learning Achievement Using Model Cycle-5e Assisted Statistics the Module}

\begin{abstract}
This study aims to describe effectiveness use of Model Cycle-5E assisted modul Statistika to increase the student's achievement in subject class XII SMAN 4 Yogyakarta. The classroom action research steps in cycle I are: arrange the planning to have development, conduct the planning, observe the effect of the action, and reflect on the things that have been done. If the results obtained in one cycle is not in accordance with targeted, it will repeat again in the next cycle, and so on, up to cycles III. The results of this research after the use of Model Cycle-5E modul Statistika assisted proved to be effective: 1) The learning achievement class XII SMAN 4 Yogyakarta is increase. Seen from the increasing in mastery learning students each cycle of: 13 students in cycle I, 27 students in cycle II, 29 students at the third cycle. There is an increasing in the percentage of completeness each cycle, 40.63\% in cycle I, 84,38\% in cycle II, and $100 \%$ in cycle III. Learning achievement of at least a $80 \%$ of students achieving mastery minimal completeness criteria 75. 2) The using of Model Cycle-5E assisted modul Statistika good because of the positive response from students. This can be seen from the interviewing and learning Model Cycle-5E shows most of the students give positive responses and few students give negative feedback.
\end{abstract}

Keywords: Cycle-5e; statistics module; learning achievement.

\section{Pendahuluan}

Multi tafsir bisa terjadi pada pembelajaran Matematika, karena Matematika adalah bahasa umum untuk mengajukan ide atau pengetahuan secara resmi dan butuh ketelitian. Matematika adalah hal yang sangat penting untuk dimengerti oleh setiap siswa baik penerapan maupun pola pikirnya, supaya siswa siap menghadapi kehidupan masa depan yang semakin kompleks. Pembelajaran matematika selalu meningkat mulai dari konkret hingga abstrak. Matematika memiliki konsep yang kompleks dan abstrak, sehingga agar konsep yang begitu kompleks dari matematika lebih mudah dipahami diperlukan adanya modul pembelajaran untuk membantu peran seorang guru (Bornok, 2014: 3). 
Kurikulum 2013 banyak membuka keleluasaan kepada guru untuk membangun kegiatan belajar dan mengajar, menaikkan prestasi belajar siswa, termasuk didalamnya memanfaatkan sumber belajar, memakai model pembelajaran, menggunakan dan mengembangkan modul pembelajaran untuk menjamin efektifitas pembelajaran. Mengembangkan dan memanfaatkan modul pembelajaran oleh seorang guru diharapkan dapat menyederhanakan konsep dari Matematika dan tidak menimbulkan kejenuhan siswa pada saat belajar serta modul pembelajaran tersebut dapat mendukung peran seorang guru dalam kegiatan pembelajaran agar lebih berhasil dan berdaya guna, serta tidak jauh menyimpang dari kompetensi yang ingin dicapai.

Modul pembelajaran adalah sebagai sarana dalam kegiatan belajar dan mengajar. Segala sesuatu yang dapat dimanfaatkan untuk membangkitkan gagasan, ketertarikan, mencoba, dan keahlian atau kecakapan pebelajar tersebut sehingga dapat memajukan berlangsungnya proses belajar atau kegiatan pembelajaran. Modul adalah materi pada bahan pelajaran, disusun dan ditampilkan dalam bentuk tulisan sehingga pembaca dapat menyerap materi secara mandiri (Abdul Majid, 2012: 176).

Salah satu cara agar pembelajaran menjadi menarik yaitu memanfatkan bahan ajar yang menyenangkan, yang dapat membuat siswa merasa tertarik dan senang mempelajari materi pada pembelajaran tersebut. Bahan ajar merupakan sekumpulan materi pelajaran yang mampu mendukung tercapainya tujuan kurikulum yang diatur secara sistemastis dan lengkap sehingga menciptakan suasana belajar yang menggembirakan, memudahkan siswa untuk belajar dan guru untuk mengajar. Salah satu bentuk bahan ajar adalah modul pembelajaran. Ada modul pembelajaran yang berbentuk modul cetak dan modul elektronik (Seputarpengertian.blogspot.com, 2020).

Modul pembelajaran yang sering dimanfaatkan dalam proses pembelajaran adalah modul cetak. Modul merupakan sarana pembelajaran yang berupa manuskrip atau sarana cetak yang sering dipakai oleh guru dan siswa dalam kegiatan pembelajaran. Modul adalah bahan ajar cetak yang dikembangkan untuk dipelajari secara mandiri oleh peserta pembelajaran. Modul disebut juga sebagai sarana pembelajaran yang digunakan oleh perseorangan karena dilengkapi dengan petunjuk untuk belajar dalam keadaan berdiri sendiri. Dalam pengertian pengguna modul mampu melakukan pelaksanaan pembelajaran tanpa kunjungan guru untuk membimbingnya (Buku 4 PKB, 2019: 37).

Peserta didik akan merasa tertarik mempelajari Matematika ketika ikut aktif dalam proses pembelajaran. Oleh karena itu, materi pada modul Statistika diharapkan dapat membuat siswa ikut berinteraksi untuk menemukan suatu konsep yang baru maupun dalam mengerjakan latihan-latihan sehingga diperlukan sebuah model dari modul yang dapat mengajak interaksi siswa ke dalam modul tersebut. Salah satu model yang dapat dimanfaatkan dalam pembelajaran adalah Model Cycle-5E. Model Cycle-5E merupakan model pembelajaran yang berpusat pada siswa, sehingga dapat menaikkan aktivitas dan daya cipta siswa (Miftahul Huda, 2013: 176).

Model Cycle-5E merupakan rangkaian tahap kegiatan, agar siswa dapat menguasai kecakapan yang diperlukan dalam pembelajaran dengan berperan aktif. Model Cycle-5E dikembangkan oleh Rodger W. Bybee terdiri dari beberapa fase yaitu: 1) Fase Engage, 2) Fase Explore, 3) Fase Explain, 4) Fase Elaboration, 5) Fase Evaluate. (http://mediafunia.blogspot.com, 2016)

Kelima fase tersebut dapat digambarkan seperti berikut:

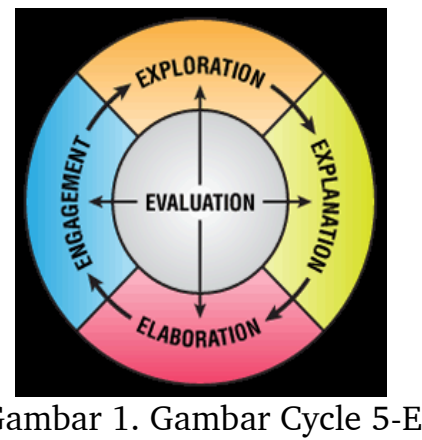

Pemilihan materi yang disajikan juga harus dipertimbangkan dan dianalisis dengan baik berdasarkan tingkat kesulitan dan kesesuaian dengan materi yang diajarkan agar mendapat hasil yang optimal. Salah satu pokok bahasan dalam Matematika adalah Statistika diajarkan pada kelas XII SMA/MA. Pokok bahasan Statistika untuk SMA/MA kelas XII adalah: ukuran data kelompok (Permendikbud No.24, 2016).

Materi Statistika adalah materi yang sulit bagi siswa, karena berhubungan dengan angkaangka dan berbagai rumus statistika dalam melakukan analisa dan mengambil keputusan. Dalam proses pembelajaran siswa masih mengandalkan guru sehingga aktivitas dan kemandirian siswa kurang baik.

"Prestasi" adalah kata yang asal mulanya dari istilah Belanda yaitu prestatie. Dalam 
percakapan Bahasa Indonesia berubah menjadi "prestasi" yang mempunyai pengertian "hasil kerja keras" sebutan "prestasi belajar" (acheievement) berlainan dengan "hasil belajar" (learning outcome). Prestasi belajar biasanya berhubungan dengan segi pengetahuan, sementara hasil belajar mencakup segi membentuk kepribadian siswa. Istilah prestasi sebagian besar digunakan di berbagai aspek dan kegiatan, diantaranya seni, olahraga, dan pendidikan, khususnya pembelajaran (Zainal Arifin, 2013: 12).

Prestasi belajar Matematika siswa SMAN 4 Yogyakarta masih tergolong rendah. Kriteria Ketuntasan Minimal (KKM) Matematika pada tahun 2019 adalah 75, tetapi sebagian besar siswa nilainya masih kurang dari KKM. Berdasarkan hasil observasi selama pembelajaran di kelas XII IPA 1 s.d 4, ada satu kelas yang memiliki prestasi belajar Matematikanya berbeda dengan kelas lainnya. Kelas XII IPA-3 mempunyai perbedaan dalam prestasi belajar Matematika.

Persentase Ketuntasan Siswa Kelas XII Semester Ganjil pada Uji Kompetensi Mata Pelajaran Matematika SMAN 4 Yogyakarta ditampilkan pada tabel 1 berikut:

Tabel 1. Persentase Nilai Siswa

\begin{tabular}{ccccc}
\hline Tahun & Kelas & \multicolumn{2}{c}{ Jumlah siswa } & Persentase \\
\cline { 3 - 4 } Ajaran & XII & \multicolumn{2}{c}{ KKM 75 } & ketuntasan \\
\cline { 3 - 5 } & & KKM & $<$ KKM & $(\%)$ \\
\hline $2019-$ & IPA-1 & 14 & 19 & 42,42 \\
2020 & IPA-2 & 14 & 19 & 42,42 \\
& IPA-3 & 10 & 22 & 31,25 \\
& IPA-4 & 12 & 21 & 36,36 \\
\hline
\end{tabular}

Bersumber pada paparan tabel 1 maka penulis terdorong untuk memanfaatkan modul Matematika dengan model Cycle-5E pada pokok bahasan Statistika untuk kelas XII IPA SMA/MA. Modul yang dikembangkan dan digunakan ini menggunakan Model Cycle-5E sehingga modul ini memiliki tahapan-tahapan yang terdapat dalam Model Cycle-5E yaitu dapat menarik perhatian (engage). Modul pembelajaran ini mengajak siswa mengeksplorasi pengetahuan yang dimiliki tentang ukuran data kelompok yang disajikan dalam bentuk tabel dan grafik yaitu bagian eksplorasi (exploration). Pada tahap explain siswa harus menjelaskan dan menyimpulkan dengan bahasa siswa masing-masing. Kemudian pada tahap pengembangan (elaboration) siswa dituntut untuk mengembangkan pemahaman yang mereka dapatkan baik untuk menyelesaikan pemecahan masalah maupun pengembangan dalam kehidupan sehari-hari. Kemudian dilanjutkan pada tahap terakhir yaitu evaluasi (evaluation), pada tahap ini modul pembelajaran yang dikembangkan berisi soal-soal ukuran pemusatan dan penyebaran data yang disajikan dalam bentuk tabel dan grafik untuk mengukur tahap pengertian siswa terhadap materi yang sudah dipelajari. Setelah modul dibuat, modul dapat digunakan untuk pembelajaran, selain itu, modul juga dapat digunakan untuk membantu proses pembelajaran dengan Model Cycle-5E.

Berdasarkan hal yang sudah diuraikan, penulis tertarik untuk melakukan penelitian pembelajaran berbasis modul Statistika pada pembelajaran Matematika dengan judul: "Penggunaan Model Cycle-5E. Berbantu Modul Statistika Dalam Meningkatkan Prestasi Belajar Siswa Kelas XII IPA SMAN 4 Yogyakarta Tahun 2019".

Menurut latar belakang yang sudah dijelaskan sebelumnya maka rumusan masalah dalam penelitian ini adalah: 1) Bagaimana penggunaan Model Cycle-5E berbantu modul statistika efektif dalam meningkatkan prestasi belajar matematika siswa kelas XII IPA SMAN 4 Yogyakarta tahun pelajaran 2019-2020? 2) Bagaimana pencapaian hasil penggunaan Model Cycle-5E berbantu modul Statistika dalam meningkatkan prestasi belajar Matematika siswa kelas XII IPA SMAN 4 Yogyakarta tahun ajaran 2019-2020?

Berdasarkan rumusan masalah tujuan penelitian ini adalah: 1) Mendeskripsikan penggunaan model Cycle-5E berbantu modul statistika dalam meningkatkan prestasi belajar Matematika siswa kelas XII IPA SMAN 4 Yogyakarta tahun pelajaran 2019-2020. 2) Mendeskripsikan pencapaian hasil penggunaan model Cycle-5E berbantu modul statistika dalam meningkatkan prestasi belajar Matematika siswa kelas XII IPA SMAN 4 Yogyakarta tahun pelajaran 2019-2020.

Penelitian ini diharapkan memberi manfaat: 1) Bagi siswa dapat memberi motivasi untuk meningkatkan prestasi belajar, meningkatkan motivasi dan partisipasi dalam pembelajaran matematika. 2) Bagi Guru dapat dijadikan rujukan dan menambah wawasan tentang model Cycle-5E berbantu modul statistika, sebagai rujukan salah satu alternatif untuk meningkatkan prestasi belajar Matematika dengan menggunakan model Cycle-5E berbantu modul Statistika. 3) Bagi sekolah sebagai masukan untuk pengembangan guru dalam pembelajaran, dan menciptakan suasana kelas yang kondusif.

\section{Metode Penelitian}

Pada dasarnya penelitian ini merupakan penelitian tindakan kelas (Classroom Action Research). Penelitian ini memakai pendekatan 
kualitatif karena sumber data didapat langsung dari permasalahan yang dihadapi guru atau peneliti dan data deskriptif berupa kata-kata atau kalimat. Penyelesaian dari permasalahan tersebut dirancang berdasarkan kajian teori pembelajaran dan input dari lapangan.

Pada semester 1 Tahun Ajaran 2019-2020 dari bulan Agustus sampai dengan bulan Oktober 2019 penelitian ini dilaksanakan. Penelitian di SMA Negeri 4 Yogyakarta, yang beralamat di Jalan Magelang Km.4 Karangwaru Lor Yogyakarta.

Sebagai subjek dalam penelitian ini yaitu siswa kelas XII IPA-3 SMAN 4 Yogyakarta, yang jumlahnya 32 terdiri dari 15 siswa laki-laki dan 17 siswa perempuan sebagai subjek penelitian.

Alat Bantu yang dipakai untuk meneliti siswa kelas XII IPA-3 SMAN 4 Yogyakarta. tahun ajaran 2019 adalah alat tes, modul Statistika, dan teman sejawat

Data yang diteliti merupakan data primer yaitu meneliti sumber obyek secara langsung siswa kelas XII IPA-3 SMAN 4 Yogyakarta tahun 2019. Sebagai objek penelitian adalah partisipasi dan prestasi belajar siswa dalam pembelajaran, pada proses pembelajaran ukuran pemusatan dan penyebaran data yang disajikan dalam bentuk tabel dan diagram dengan model pembelajaran Cycle-5E berbantu modul statistika.

Rancangan penyelesaian masalah yang dimaksud adalah tindakan berupa penerapan model pembelajaran Cycle-5E berbantu modul Statistika dalam pengajaran materi ukuran pemusatan dan penyebaran data yang disajikan dalam bentuk tabel dan diagram. Penerapan model pembelajaran Cycle-5E ini melalui tindakan siklus dalam setiap pembelajarannya. Penelitian Tindakan Kelas ini menggunakan model Kemmis dan Taggart, yang terdiri dari empat tahap yaitu perencanaan tindakan, pelaksanaan tindakan dan pengamatan pembelajaran, dan refleksi.

Jenis data yang didapat berupa data kuantitatif dan data kualitatif yang terdiri dari data prestasi belajar siswa, dan catatan kejadian saat pembelajaran model Cycle-5E berlangsung.

Data tentang penambahan prestasi belajar siswa pada pokok bahasan ukuran data kelompok yang disajikan dalam bentuk tabel dan diagram, diambil dengan memberikan tes kepada siswa. Tes umumnya bersifat mengukur, dalam hal ini tes yang dipakai adalah tes hasil belajar untuk menilai prestasi belajar matematika setelah menyelesaikan satu pokok bahasan tertentu pada satu semester. Bentuk tes adalah essay yang disusun berdasarkan kisi-kisi tes sesuai standar kompetensi untuk menilai prestasi belajar matematika. Bentuk ini paling luwes untuk menilai berbagai tingkatan hasil belajar. Hasil tes prestasi tersebut dimanfaatkan untuk mendapatkan data prestasi belajar. Tes digunakan untuk mendapatkan data dari variabel prestasi belajar matematika. Tes adalah alat pengumpul data yang berbentuk uraian pertanyaan atau butir soal.

Observasi dilaksanakan oleh kolaborator untuk memantau atau mengamati individu atau kelompok secara langsung saat pembelajaran berlangsung, pelaksanaan tindakan atau proses belajar mengajar dalam melaksanakan pembelajaran ukuran pemusatan dan penyebaran data yang disajikan dalam bentuk tabel distribusi frekuensi dan histogram dengan menggunakan metode Cycle-5e berbantu modul Statistika. Observasi dilaksanakan dengan menggunakan teknik dan alat khusus seperti blangko-blangko, checklist, atau daftar isian yang sudah dipersiapkan sebelumnya oleh guru.

Wawancara dilakukan untuk memperoleh data penelitian. Wawancara dilakukan terhadap siswa yang menonjol, baik dari segi positif dan negatif. Wawancara terhadap siswa yang menonjol dari segi positif untuk mengetahui apakah pembelajaran ukuran pemusatan dan penyebaran data dalam bentuk tabel dan diagram dengan menggunakan metode Cycle-5e berbantu modul Statistika dapat menaikkan prestasi belajar siswa kelas XII IPA-3 SMAN 4 Yogyakarta.

Sesuai dengan jenis data, teknik analisis data yang dipakai pada penelitian ini adalah teknik kualitatif dan teknik kuantitatif yaitu: Analisis Penilaian prestasi belajar dilakukan untuk mengetahui hal-hal yang didapat siswa dalam belajar ukuran pemusatan dan penyebaran data yang disajikan dalam bentuk tabel dan diagram dengan cara pembelajaran Cycle-5E berbantu modul Statistika, yaitu meningkatkan prestasi belajar akademik, mampu membantu siswa dalam memahami konsep-konsep yang rumit. Prestasi belajar meningkat bila minimal sejumlah $80 \%$ siswa mencapai lebih dari Kriteria Ketuntasan Minimal 75. Pada penelitian ini tes disusun peneliti berdasarkan kisi-kisi. Dilakukan dengan tes uraian yang dilakukan sebanyak 3 kali putaran, yaitu setelah guru memberikan, serta setelah siswa mendapat penjelasan dari kelompok lain yang presentasi. Setiap kali tes diberikan 4 soal uraian.

Analisis Penilaian Proses dilakukan dengan cara memantau dan mengelilingi siswa yang sedang melakukan kegiatan pembelajaran model Cycle-5E berbantu modul statistika dalam kelompok masing-masing. Pada kegiatan ini kolaborator mendengarkan, memperhatikan dan 
memantau kegiatan yang dilakukan oleh siswa, sehingga guru dapat menilai proses pembelajaran yang sedang berlangsung.

Kriteria Keberhasilan prestasi belajar kelas XII IPA-3 dikatakan meningkat bila minimal sejumlah $80 \%$ siswa mencapai lebih dari Kriteria Ketuntasan Minimal 75.

\section{Hasil dan Pembahasan}

Penggunaan secara tepat penggunaan Model Cycle-5E berbantu modul Statistika dapat menaikkan prestasi belajar siswa kelas XII IPA 3 semester ganjil di SMAN 4 Yogyakarta pada pokok ukuran pemusatan dan penyebaran data pada diagram. Kekurangan siklus I yaitu:

Pada fase Explore (Menyelidiki) yaitu tahap di mana siswa berdiskusi bersama kelompoknya untuk menyelesaikan suatu permasalahan ada siswa yang menyendiri tidak ikut bergabung untuk belajar bersama kelompoknya. Adanya rasa saling menyayangi, menghargai, mempunyai disiplin diri, dan tanggungjawab berperilaku positif dalam membangun suatu kelompok sosial adalah maksud membuat kelompok diskusi (Hamzah Uno, 2012: 22).

Jika ada siswa yang tidak berbaur dengan kelompoknya maka tujuan yang ingin dicapai tidak terjadi, oleh karena itu siswa dari kelompok itu diberikan arahkan agar ikut aktif dalam kegiatan diskusi kelompok.

Pada fase Explain (Menjelaskan) ada sedikit hambatan ketika kelompok akan menyajikan hasil diskusi pada screen proyektor (layar). LCD mati sehingga Laptop tidak dapat tersambung sehingga siswa menulis hasil diskusinya di kertas karton bukan di lembar kerja dari modul Statistika. Manfaat modul pembelajaran adalah membantu keberhasilan pembelajaran yaitu: menarik hati kepedulian siswa, sehingga membangun ketertarikan, semangat, kegiatan dan daya cipta belajar siswa. Manfaat modul pembelajaran yang lainnya adalah meringankan dan melancarkan penyajian materi saat proses belajar dan mengajar. Diperlukan kesiapan guru dalam hal antisipasi jika ada kendala dalam pembelajaran, yaitu mempersiapkan alat lain yang di gunakan untuk menyajikan sumber belajar.

Pada fase Elaborate (Pengembangan) siswa tidak melakukan penyelidikan, pemecahan masalah, dan membuat keputusan. Siswa tidak menggunakan pengetahuan yang diperoleh pada tahap sebelumnya dan mengembangkannya karena waktu yang digunakan sudah terpakai pada saat siswa menulis hasil diskusinya pada kertas karton.
Kekurangan siklus I diperbaiki pada siklus II, perbaikan yang dilakukan guru adalah: tidak mengubah anggota kelompok diskusi yang sudah heterogen tetapi mengingatkan siswa untuk bersunguh-sunguh dalam kegiatan pembelajaran; mengalokasi waktu dengan baik sehingga semua fase dapat terlaksana; Guru menyediakan alat lain untuk presentasi hasil diskusi.

Sebagian besar siswa mulai aktif bekerjasama dengan kelompoknya saat pelaksanaan siklus II. Pada fase Explain (Menjelaskan) ternyata sebagian kelompok keliru dalam hal perhitungan. Keadaan ini berlangsung karena siswa kurang cermat dalam hal perhitungan dan beberapa siswa dari satu kelompok salah ketika menetapkan tepi bawah kelas modus, dan median. Ternyata sebagian siswa kelas XII IPA-3 kurang terampil dalam perhitungan karena terbiasa menggunakan kalkulator dalam berhitung dan untuk menentukan nilai rata-rata yang menggunakan nilai tengah perhitungannya besar jadi harus menggunakan kalkulator. Siswa keliru dalam pengambilan tepi bawah kelas modus karena salah melihat, seharusnya siswa memberi tanda untuk kelas modus dan median menggunakan stabilo.

Kekurangan siklus II diperbaiki pada siklus III, perbaikan yang dilakukan adalah siswa diminta untuk: lebih sungguh-sungguh lagi berpartisipasi bersama kelompoknya, lebih seksama lagi saat melakukan perhitungan. Pembelajaran berjalan lebih baik pada siklus III dari siklus II, siswa lebih aktif lagi dalam hal presentasi kelompok atau pada bagian Explain (Menjelaskan). Kelompok 1 presentasi menyajikan hasil diskusinya dan kelompok lain tidak menanggapi presentasi karena sebagian besar kelompok bisa menentukan ukuran penyebaran data pada tabel dan grafik.

Data prestasi belajar SMAN 4 Yogyakarta menggunakan Model Cycle 5-E berbantu Modul Statistika dengan materi ukuran pemusatan dan penyebaran data dapat dilihat pada tabel 2 berikut:

Tabel 2. Nilai Hasil Tes Siklus I, II, dan III

\begin{tabular}{llll}
\hline Keterangan & Siklus I & Siklus II & Siklus III \\
\hline Jumlah & 2256 & 2447 & 2573 \\
rata-rata & 70,6 & 76,5 & 88,7 \\
Nilai Tertinggi & 96 & 90 & 100 \\
Nilai Terendah & 53 & 50 & 75 \\
Tuntas & 13 & 27 & 29 \\
Tidak Tuntas & 19 & 5 & 0 \\
Peserta Tes & 32 & 32 & 29 \\
\% Ketuntasan & 40,63 & 84,38 & 100 \\
\hline
\end{tabular}


Nilai rata-rata kelas siklus I pada table adalah 70,6; dan siswa yang nilainya sudah tuntas berjumlah 13 dari 32 siswa. Untuk persen ketuntasannya adalah 40,63\%. Sedangkan pada Siklus II yang pembelajarannya dilakukan dengan model Cycle-5E berbantu modul Statistika rata-ratanya adalah 76,5 dan nilai siswa sudah tuntas 27 dari 32 siswa, persen ketuntasannya adalah $84,38 \%$. Di Siklus III nilai rata-ratanya adalah 88,7. Total siswa yang nilainya sudah melebihi KKM adalah 29 dari 29 total siswa yang ikut tes pada siklus III, persen ketuntasannya adalah $100 \%$.

Berdasarkan data nilai siklus tersebut dapat diambil kesimpulan bahwa pada pembelajaran Model Cycle-5E terdapat peningkatan dalam hal rerata nilai, jumlah siswa yang tuntas, dan persentase ketuntasan serta mengalami peningkatan dalam hal perolehan nilai untuk sebagian besar siswa dan penilaian kelompok. Penilaian kelompok peserta bisa kita amati pada tabel 3 berikut:

Tabel 3. Nilai Kelompok Antar Siklus

\begin{tabular}{cccc}
\hline \multirow{2}{*}{ KEL. } & \multicolumn{3}{c}{ NILAI SIKLUS } \\
\cline { 2 - 4 } & SIKLUS I & SIKLUS II & SIKLUS III \\
\hline 1 & 95 & 95 & 100 \\
2 & 85 & 95 & 95 \\
3 & 85 & 95 & 95 \\
4 & 75 & 80 & 95 \\
5 & 85 & 88 & 88 \\
6 & 75 & 75 & 75 \\
7 & 80 & 95 & 95 \\
8 & 85 & 95 & 95 \\
\hline Rata-rata & 83,13 & 89,75 & 92,25 \\
\hline
\end{tabular}

Tampak bahwa dari siklus I s.d III ada peningkatan dalam hal rata-rata, total siswa yang nilainya di atas KKM, persen ketuntasan. Keadaan ini menunjukkan bahwa pembelajaran Ukuran pemusatan dan penyebaran data pada tabel dan grafik dengan Model Cycle-5E dapat mencapai ketuntasan yang maksimal dan rata-ratanya meningkat dan tidak jauh berbeda nilai antar siswa satu dengan siswa lain. Berdasarkan hasil wawancara ada siswa yang berbeda dalam hal perolehan nilai hal ini disebabkan memang mereka kurang terampil dalam hal perhitungan.

Berdasarkan data nilai siklus tersebut dapat diambil kesimpulan bahwa pada pembelajaran Model Cycle-5E terdapat peningkatan dalam hal rerata nilai, jumlah siswa yang tuntas, dan persentase ketuntasan serta mengalami peningkatan dalam hal perolehan nilai untuk sebagian besar siswa dan penilaian kelompok.

Penggunaan Model Cycle-5E berbantu modul Statistika, efektif dalam meningkatkan prestasi belajar kelas XII IPA-3 SMAN 4
Yogyakarta tahun 2019, berdasarkan hasil wawancara dengan kelompok atas karena: Metodenya runtut dan simpel sehingga meringankan siswa dalam menguasai materi; variasi dalam pembelajaran tidak monoton karena terdiri dari beberapa fase sehingga tidak membosankan siswa dalam mengikuti pembelajaran; Modul Statistika membantu mereka memahami teori dan konsep, membantu mereka dalam membuat tabel dan menggambar grafik, membantu mereka dalam perhitungan menentukan ukuran data kelompok dalam bentuk diagram; Metodenya menarik karena mempermudah siswa bertanya kepada teman jika melewati permasalahan dalam memahami materi jika siswa malu bertanya pada guru, mudah memahami materi dalam setiap pembelajaran dan materi yang dipahami masih melekat dalam ingatan sehingga jika ulangan tidak perlu banyak menghafal rumus.

Hasil observasi pembelajaran bisa kita amati dari tabel 4 berikut:

Tabel 4. Penilaian Evaluasi Pembelajaran

\begin{tabular}{lcc}
\hline & Skor Nilai & Kategori \\
\hline Siklus I & 83,13 & Baik \\
Siklus II & 89,75 & Baik \\
Siklus III & 92,25 & Amat Baik \\
Rata-rata & 88,38 & Baik \\
\hline
\end{tabular}

Dari tabel terlihat bahwa penggunaan model Cycle-5E berbantu modul Statistika siswa bersunguh-sungguh dalam mengikuti aktivitas belajar mengajar meskipun ada beberapa siswa yang tidak bekerjasama dengan kelompoknya, pada penilaian Lembar Kerja Siswa diperoleh rata-rata nilai kelompok 88,38 dengan kategori baik.

Hasil observasi belajar pada siklus II menunjukkan bahwa penggunaan Model Cycle$5 E$ berbantu modul Statistika siswa bersungguhsungguh dalam mengikuti pembelajaran, tetapi ada beberapa individu masih tidak bekerjasama dalam kelompok, dan ada kesalahan dalam perhitungan. Pada penilaian lembar kerja pada modul diperoleh rata-rata nilai kelompok 89,75 dengan kategori baik, sehingga dapat dikatakan pelaksanaan pembelajaran pada siklus II baik.

Hasil pemantauan pada proses belajar dan mengajar di siklus III menunjukkan bahwa penggunaan Model Cycle-5E berbantu modul Statistika semua siswa bersunguh-sungguh dalam mengikuti pembelajaran. Semua kelompok bekerjasama secara bersungguh-sungguh dan sebagian besar kelompok aktif dalam presentasi terbukti pada penilaian lembar kerja pada modul diperoleh rata-rata nilai kelompok 92,25 dengan kategori amat baik, sehingga dapat dikatakan 
pelaksanaan pembelajaran pada siklus III amat baik.

Nilai kenaikan rata-rata pada setiap siklus tampak pada gambar 3 berikut :

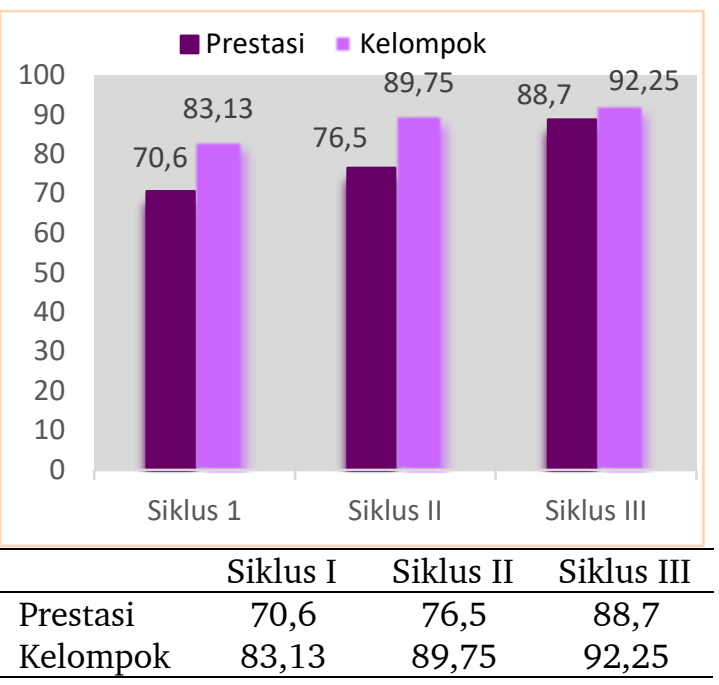

Gambar 2. Nilai rata-rata nilai prestasi dan kelompok

Tingkat aktivitas dari siklus satu sampai tiga, yang diharapkan adalah: Siswa mempunyai keterampilan dan daya cipta serta selalu semangat dalam proses pembelajaran ukuran pemusatan dan penyebaran data pada tabel dan grafik, Siswa terbiasa bekerjasama dan berdiskusi dalam kelompok, Guru memiliki kemampuan membuat dan menggunakan Model Cycle-5E berbantu modul statistika khususnya pada mata pelajaran Matematika, Prestasi siswa dalam pelajaran matematika meningkat

Pada pembelajaran model Cycle-5E, hal yang diperoleh siswa adalah: Meningkatkan kemampuan siswa ketika menyelesaikan tugas akademik; Pembelajaran Model Cycle-5E mampu menunjang siswa dalam menguasai persepsi; Penerimaan siswa terhadap berbagai keragaman, Siswa menyambut rekan belajar yang mempunyai berbagai macam perbedaan latar belakang. Perbedaan tersebut antara lain perbedaan suku, agama, kemampuan akademik, jenis kelamin, dan tingkat sosial; Mengembangkan ketrampilan sosial siswa. Ketrampilan sosial yang dimaksud antara lain: berbagi tugas, siswa antusias bertanya, siswa dapat menghargai pendapat teman lain, memancing teman untuk bertanya, siswa mau menerangkan konsep atau gagasan, bekerja dalam kelompoknya, dan sebagainya.

Pembelajaran ukuran data kelompok pada tabel dan grafik dengan Model Cycle-5E berbantu modul Statistika menjadi lebih berarti karena: Siswa lebih terbuka terhadap sesama teman, sehingga materi yang belum dimengerti akan ditanyakan kepada temannya tanpa ada rasa malu dan takut dan siswa dapat belajar secara lebih aktif karena mereka dilibatkan dalam pembelajaran; Siswa memiliki tanggung jawab sebagai anggota kelompok yang ikut menentukan keberhasilan kelompoknya membuat siswa berusaha untuk bekerjasama dengan teman secara maksimal, sehingga siswa berusaha merumuskan dan menyampaikan gagasan kepada kelompok, siswa berusaha untuk menyampaikan pendapat kepada kelompok lain.

\section{Simpulan dan Saran}

Penggunaan Model Cycle-5E berbantu modul Statistika terbukti efektif dalam menaikkan prestasi belajar siswa kelas XII IPA-3 SMAN 4 Yogyakarta tahun ajaran 2019-2020. Tampak ditinjau dari penambahan ketuntasan belajar siswa setiap siklus dari 13 siswa pada siklus I menjadi 27 siswa pada siklus II, 29 siswa pada siklus III. Ada peningkatan presentase ketuntasan setiap siklus, dari 40,63\% pada siklus I naik menjadi $84,38 \%$ pada siklus II, dan $100 \%$ pada siklus III. Prestasi belajar minimal sejumlah $80 \%$ siswa mencapai lebih dari Kriteria Ketuntasan Minimal 75.

Penggunaan secara tepat Model Cycle-5E berbantu modul statistika dapat menaikkan prestasi belajar Matematika siswa kelas XII IPA-3 adalah siswa ikut aktif dalam kelompok, kelompok siswa harus heterogen (baik jenis kelamin maupun kepandaian), siswa teliti dalam perhitungan.

Pencapaian hasil penggunaan Model Cycle5E berbantu modul Statistika dalam meningkatkan prestasi belajar siswa menurut hasil tes dan observasi tiap siklus, adanya tanggapan positif terhadap pembelajaran Model Cycle-5E berbantu modul Statistika. Hal ini dapat diamati dari hasil tanyajawab terhadap sejumlah siswa dan observasi pembelajaran Model Cycle-5E berbantu modul Statistika yang menunjukkan sebagian besar siswa memberikan tanggapan positif dan beberapa siswa memberikan tanggapan negatif, memberikan dampak yang lain yaitu: Pembelajaran model Cycle-5E memungkinkan siswa lebih terbuka terhadap sesama teman, menumbuhkan rasa tanggung jawab siswa sebagai anggota kelompok yang ikut menentukan keberhasilan kelompoknya membuat siswa berusaha untuk bekerjasama dengan temannya secara maksimal, sehingga siswa berusaha merumuskan dan menyampaikan gagasan kepada kelompoknya, siswa berusaha untuk menyampaikan pendapat kepada kelompok lain. 


\section{Daftar Pustaka}

Abdul Majid. (2012). Perencanaan Pembelajaran. Bandung: PT. Remaja Rosdakarya.

Bornok Sinaga, dkk. (2014). Buku Guru Matematika. SMA / MA / SMK / MAK Kelas XI. Jakarta: Kementerian Pendidikan dan Kebudayaan.

Buku 4. (2019). Pembinaan dan Pengembangan Profesi Guru. Pedoman Kegiatan Pengembangan Keprofesian Berkelanjutan Dan Angka Kreditnya. Jakarta: Kementerian Pendidikan dan Kebudayaan.

Miftahul Huda, M.Pd. (2013). Model-model Pengajaran dan Pembelajaran. Yogyakarta: Pustaka Pelajar.

Permendikbud No.24. (2016). Tentang Kompetensi Inti dan Kompetensi Dasar.
Jakarta: Kementerian Pendidikan dan Kebudayaan.

Prof. Dr. Hamzah B. Uno, M.Pd. (2012). Model Pembelajaran Menciptakan PBM yang Kreatif dan Efektif. Jakarta: Bumi Aksara.

Zainal Arifin. (2013). Evaluasi pembelajaran. Bandung: PT. Remaja Rosdakarya.

Nur Fatin. (2019). Pengertian bahan ajar serta bagian-bagiannya. Retrieved Juli 28, 2019 https://seputarpengertian.blogspot.com

Media Funia. (2016). Model pembelajaran siklus belajar 5e. Retrieved Juli 28, 2019 from http://mediafunia.blogspot.com

Zuhdha Basofi Yudha. (2019). problematikapembelajaran-statistika. Retrieved maret 28 , 2019 from https://www.slideshare.net 